\title{
Partisipasi Masyarakat Dalam Pengembangan Desa Wisata (Studi Kasus Desa Menang Kecamatan Pagu Kabupaten Kediri)
}

\author{
Maya Sajidah Salsabila ${ }^{1}$, Agus Machfud Fauzi
}

\author{
Affiliation \\ ${ }^{1}$ Universitas Negeri Surabaya \\ ${ }^{2}$ Universitas Negeri Surabaya
}

\section{Correspondence}

Maya Sajidah Salsabila, Faculty of Sociology, Universitas Negeri Surabaya, Jl. Lidah Wetan, Lidah Wetan, Kec. Lakarsantri, Kota SBY, Jawa Timur 60213, Email:mayasajidah@gmail.com

\begin{abstract}
The village won has tourism potential, namely Petilasan Sri Aji Jaya Baya and star fruit. The purpose of this study was to determine community participation in the development of a tourist village in Menang Village which eventually became one of the sources of economic improvement for the surrounding community. The method used in this research is qualitative because it can provide an overview of community participation in the development of a tourist village. The analysis uses Max Weber's theory of rationality. Max Weber's rationality theory can explain community participation in developing tourist villages. Collecting information by means of interviews, observation, and documentation. Based on the research results, there is community participation in the form of ideas, energy, and creativity. This is done by the community to work together to develop the star fruit tourism village in an effort to improve the community's economy.
\end{abstract}

Keywords: Participation; Community; Tourism village.

Article Information:

Submitted 26 April 2021|Revised 25 July 2021|Accepted 26 July 2021

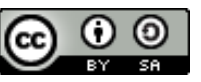

Copyright (C 2021 by the author(s). This article is published by Universitas Gadjah Mada, Indonesia under the Creative Commons Attribution (CC BY 4.0) license. Anyone may reproduce, distribute, translate, and create derivative works of this article (for both commercial and noncommercial purposes), subject to full attribution to the original publication and author(s). The full terms of this license may be seen at http://creativecommons.org/licenses/by/4.0/legalcod 


\section{Pendahuluan}

Setiap daerah mempunyai sumber daya manusia dan sumber daya alam yang bernilai lebih dibandingkan dengan daerah lain (Paramitha, Kagungan, \& Mulyana, 2020). Nilai lebih tersebut menjadi daya tarik bagi orang lain. Daya tarik membutuhkan proses untuk mengelola dan mengembangkan secara berkelanjutan. Sama dengan pariwisata yang mempunyai kekayaan hayati dan non-hayati sehingga dapat meningkatkan pendapatan daerah serta mensejahterakan masyarakat (Sunarta \& Arida, 2017). Menurut UU No. 10 Tahun 2009 tentang Kepariwisataan dijelaskan bahwa pariwisata merupakan kegiatan wisata yang didukung dengan fasilitas dari masyarakat, pemerintah, dan pemerintah daerah. Salah satu bentuk kepariwisataan ini yaitu desa wisata.

Desa wisata merupakan daerah sebagai tujuan untuk mengimplikasikan daya tarik, fasilitas, dan aksesbilitas yang menyatu dengan tradisi di masyarakat (Simanungkalit et al., 2019:8). Desa wisata memperlihatkan adanya potensi yang diunggulkan. Salah satu daerah yang mempunyai potensi yaitu Desa Menang Kecamatan Pagu Kabupaten Kediri. Potensi yang dimiliki Desa Menang yaitu buah Belimbing dan wisata Petilasan Sri Aji Jaya Baya. Desa Menang menjadi sentra produksi buah Belimbing yang mayoritas terdapat di depan rumah warga. Berdasarkan data potensi Desa Menang tahun 2020 hasil panen buah Belimbing sebesar 1 ton/ha dengan luas lahan 470 ha. Selain itu, Petilasan Sri Aji Jaya Baya merupakan wisata situs bersejarah dengan luas lahan 2 ha. Menurut Charlie dkk (2020), salah satu faktor penarik wisatawan yaitu budaya dan warisan objek sejarah. Minat masyarakat untuk berkunjung ke wisata bersejarah cukup tinggi. Hal ini dikarenakan adanya keinginan untuk mempelajari bangunan bersejarah dan berekreasi (Afriesta, Kurniawan, N., \& Ekasiwi, 2020). Proses pengembangan potensi desa wisata tersebut melibatkan partisipasi masyarakat lokal (Irtifah \& Bondowoso, 2019). Menurut Suharto (2005), pengembangan masyarakat lokal merupakan tahapan untuk menggambarkan kemajuan sosial dan ekonomi bagi masyarakat dengan partisipasi aktif serta inisiatif (Suharto, 2005).

Sumber daya manusia dipresentasikan sebagai sesuatu yang mempunyai potensi, kualitas, dan keterampilan. Setiap anggota masyarakat mempunyai kewajiban menentukan tujuan dan strategi yang sesuai untuk mewujudkan harapan yang telah disusun sebelumnya. Desa Menang mempunyai potensi sumber daya manusia yaitu POKDARWIS (Kelompok Sadar Wisata), perkumpulan ibu-ibu PKK, dan Karang Taruna yang mengelola potensi sumber daya alamnya. Berdasarkan keterangan kepala Dusun bahwa Ibu PKK telah menciptakan olahan dari buah Belimbing berupa minuman dan makanan khas Desa Menang. Olahan minuman berupa sari buah Belimbing sedangkan olahan makanan berupa dodol. Dodol dari buah Belimbing dijadikan sebagai ikon Desa Menang dengan diberi nama produk dodol MENSO (Menang Suko).

Beberapa kurun waktu terakhir berdasarkan keterangan dari Kepala Dusun Menang pengelolaan desa wisata mengalami hambatan pada perizinan produk, pemasaran, dan pengelolaan buah Belimbing. Terlebih saat musim Mangga, harga buah Belimbing mengalami penurunan drastis hingga mencapai Rp 1.500,-/kg. Hambatan tersebut berdampak pada perekonomian warga. Selaras dengan penelitian Abawain (2019) dijelaskan bahwa pengembangan desa wisata memberikan dampak positif terhadap kesejahteraan ekonomi masyarakat (Abawin, 2019). 


\section{Maya Sajidah Salsabila}

Peningkatan ekonomi terlihat dari peningkatan pendapatan masyarakat, terpenuhinya kebutuhan keluarga seperti sandang, papan, dan pangan.

Keadaan perekonomian warga Desa Menang rata-rata berada di kelas menengah ke bawah. Sebagian besar warga bekerja sebagai petani sehingga kehidupan ekonomi bergantung pada hasil panen. Hal tersebut, mengakibatkan warga mencari pekerjaan atau peluang lain yaitu berpartisipasi dalam mengembangkan desa wisata Belimbing dan Petilasan Sri Aji Jaya Baya. Oleh sebab itu, partisipasi warga Desa Menang dalam mengembangkan desa wisata sangat dibutuhkan. Partisipasi warga selaras dengan teori tindakan sosial dari Max Weber.

Menurut Weber tindakan sosial merupakan suatu tindakan nyata yang ditunjukkan kepada orang lain (George \& Douglas, 2009). Weber membagi tindakan sosial menjadi empat yakni tindakan rasional instrumental, tindakan rasional nilai, tindakan afeksi, dan tindakan tradisional. Tindakan rasional instrumental yakni tindakan sosial yang didasarkan pada tujuan yang ingin dicapai. Tindakan rasional intrumental warga Desa Menang yaitu dengan memperhitungkan keuntungan dan kerugian dari berpartisipasi dalam mengembangkan desa wisata. Kedua, rasional nilai yakni tindakan sosial yang ingin dicapai didasarkan pada nilai. Rasional nilai dari warga Desa Menang berpartisipasi dalam mengembangkan desa wisata yakni untuk menambah penghasilan. Ketiga, tindakan afektif yakni tindakan sosial yang didasarkan pada perasaan emosi seseorang. Keempat, tindakan tradisional yakni tindakan yang didasarkan pada kebiasaan yang diwariskan. Desa wisata Menang telah dikembangkan dari nenek moyang namun masih dalam keadaan sederhana kemudian diturunkan kepada generasi selanjutnya dengan proses pengembangan yang lebih maju.

Sesuai dengan paparan di atas, maka peneliti akan menganalisis terkait partisipasi masyarakat dalam mengembangkan desa wisata di Desa Menang. Tujuan penelitian ini untuk mengetahui potensi Desa Menang, faktor pendorong dan penghambat, dan mencari tahu keikutsertaan masyarakat dalam memberikan dukungan pada pengembangan desa wisata. Manfaat dari penelitian ini ada dua yakni pertama, manfaat praktis dapat menambah informasi dan wawasan bagi peneliti lain. Kedua, manfaat teoritis penelitian ini yakni bagi masyarakat penelitian ini dapat memberikan pengetahuan tentang pengembangan desa wisata.

\section{Metode}

Penelitian ini menggunakan pendekatan kualitatif (Sugiono, 2013). Pendekatan ini dipilih untuk memaparkan kejadian yang terjadi di masyarakat. Perspektif yang digunakan peneliti adalah fenomenologi Max Weber mengenai tindakan sosial. Weber membagi tindakan sosial menjadi empat yakni tindakan rasional instrumental, tindakan rasional nilai, tindakan afeksi, dan tindakan tradisional (Ritzer \& Goodma, 2009). Peneliti menggunakan teori tersebut, karena dirasa dapat memaparkan partisipasi masyarakat Desa Menang dalam mengembangkan desa wisata.

Penelitian dilakukan di Kabupaten Kediri tepatnya di Desa Menang pada bulan Februari sampai April 2021. Sesuai dengan profil desa Menang 2021 dijelaskan bahwa jenis tanaman buah Belimbing yang mayoritas ditanam adalah Belimbing bangkok merah pada lahan seluas 470,00 
ha dengan hasil panen 1,00 ton/ha. Berdasarkan data tersebut dapat dilihat jika masyarakat Desa Menang secara keseluruhan menanam pohon Belimbing di setiap lahannya. Terlihat dari jumlah hasil panen buah Belimbing yang dihasilkan setiap bulannya adalah 10 ton/ha. Sementara itu, Wisata Petilasan Sri Aji Jaya Baya juga mempunyai pengunjung lokal ataupun luar daerah yang cukup banyak dari berbagai kalangan. Tujuan wisatawan yang berkunjung ke Petilasan Sri Aji Jaya Baya antara lain untuk mempelajari bangunan bersejarah, rekreasi, bahkan melakukan wisata religi menurut kepercayaannya. Pengunjung wisata religi biasanya akan bermalam agar memperoleh wangsit hingga mengadakan kenduri. Hal ini dipercaya doa akan terkabul saat sembahyang di Petilasan Sri Aji Jaya Baya.

Subjek yang dipilih dalam penelitian ini yakni dua (2) perangkat desa dan empat (4) warga Desa Menang. Enam subjek tersebut meliputi kepala desa (Linda Endrawati), kepala Dusun Suko (Pak Edi), Ibu Lastri (anggota PKK), Pak Agus, Mbah Suratin (juru kunci Petilasan Sri Aji Jaya Baya) dan Ibu Mujiem. Pemilihan tersebut berdasarkan kedua kelompok subjek memahami dan dapat memberikan penjelasan yang akurat sesuai kebutuhan infromasi perkembangan dan pengembangan desa wisata di Desa Menang.

Pengumpulan informasi dilakukan dengan cara observasi, wawancara, dan dokumentasi. Observasi yakni peneliti mengunjungi ke Desa Menang untuk mengetahui potensi yang dimiliki dan mengumpulkan data melalui arsip terkait profil desa. Peneliti memanfaatkan cara wawancara yakni melangsungkan proses bertanya kepada informan. Cara ini sebagai upaya untuk menyelaraskan diri kepada perangkat desa dan masyarakat agar terbuka untuk mempermudah proses pengumpulan informasi terkait partisipasi masyarakat dalam pengembangan desa wisata di desa Menang. Sedangkan proses dokumentasi yakni mengumpulkan data faktual dari arsip desa terkait potensi dan pengembangan desa serta beberapa gambar terkait potensi Desa Menang.

Informasi yang diperoleh dianalisis dengan menyusun informasi secara sederhana melalui teknik analisis oleh Miles dan Hubermas (1984). Analisis yang dimaksud yaitu interaktif dan diterapkan secara berkesinambungan hingga informasi lebih padat, akurat, mengandung makna, dan terlebih terfokus pada pembahasan partisipasi masyarakat dalam mengembangkan desa wisata. Selanjutnya data diolah dalam bentuk penjelasan atau pemaparan. Hal ini diselaraskan dengan informasi yang dianalisis untuk ditampilkan. Informasi yang ada selanjutnya digolongkan mana yang masuk rasionalitas instrumental, rasionalitas nilai, tindakan afektif, dan tindakan tradisional. Terakhir dari penelitian ini berupa penggambaran dari adanya partisipasi masyarakat dalam mengembangkan desa wisata yang belum dilakukan sebelumnya. Informasi yang telah diketahui kebenarannya maka dapat ditindaklanjuti sesuai dengan fokus penelitian.

\section{Hasil dan Pembahasan}

\section{Kondisi Demografis Desa Menang Kabupaten Kediri}

Desa Menang merupakan salah satu desa yang ada di Kecamatan Pagu Kabupaten Kediri Provinsi Jawa Timur. Batas-batas administratif Desa Menang diantaranya pada bagian utara berbatasan langsung dengan Desa Sitimerto, sebelah selatan berbatasan dengan Desa Tanjung, sebelah 
timur berbatasan dengan Desa Tengger Kidul, dan sebelah barat berbatasan dengan Desa Wates. Jumlah penduduk laki-laki berjumlah 2109 orang dan perempuan 2104 orang. Sebagian besar masyarakat Desa Menang bekerja sebagai petani dengan jumlah 452 keluarga.

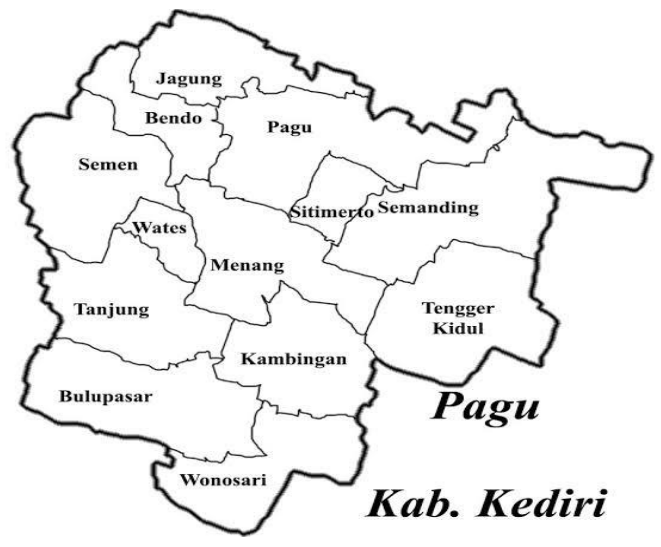

Gambar 1. Peta Desa Menang

(Sumber: Arsip Desa, 2020)

Jarak Desa Menang ke Kecamatan Pagu sekitar $1 \mathrm{~km}$. Jarak Desa Menang ke kabupaten atau kota sekitar 6 km. Jarak Desa Menang ke ibu kota Provinsi Jawa Timur 14 km. Jumlah rumah tangga yang bekerja sebagai petani sebanyak 649 orang dan buruh tani sebanyak 165 orang. Hal ini membuktikan bahwa sebagian besar warga Desa Menang bekerja sebagai petani. Oleh sebab itu, warga memilih untuk bekerja sampingan yaitu dengan berdagang. Potensi Desa Menang yaitu wisata Petilasan Sri Aji Jaya Baya dan buah Belimbing dengan luas lahan 470 ha dengan hasil panen 1 ton/ha.

\section{Identifikasi Potensi Wisata Desa Menang}

Berdasarkan temuan yang ada bahwa pada mulanya Desa Menang masuk pada desa tertinggal kemudian kepala desa memberikan inovasi dan membangkitkan desa dari ketertinggalan. Saat ini Desa Menang termasuk desa berkembang. Hal ini disebabkan adanya potensi desa yang dikembangkan menjadi desa wisata. Potensi desa tersebut yaitu:

1) Petilasan Sri Aji Jaya Baya

Petilasan Sri Aji Jaya Baya merupakan salah satu peninggalan sejarah Kerajaan Kadiri. Wisata ini sering dikunjungi oleh masyarakat baik dari dalam daerah maupun dari luar daerah.

Wisatawan yang berkunjung ke Petilasan Sri Aji Jaya Baya selain belajar sejarah juga berwisata religi. Pengunjung berwisata religi datang untuk bermalam dengan harapan memperoleh wangsit dan mengadakan kenduri sebagai rasa syukur apabila terkabulnya suatu hajad. Akan tetapi, untuk mengantisipasi adanya ritual yang sesat maka kegiatan wisata religi didampingi oleh Mbah Suratin selaku juru kunci Petilasan Sri Aji Jaya Baya. 


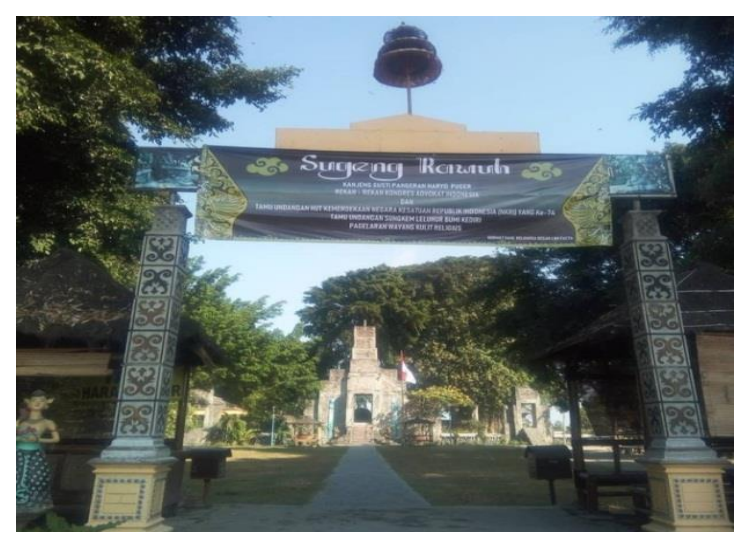

Gambar 2. Wisata Petilasan Sri Aji Jaya Baya

(Sumber: Data Primer)

Di Kecamatan Pagu, 200-meter dari utara Pamukasan Sri Aji Jayabaya berlokasi wisata Sendang Tirto Kamandanu yang diyakini masyarakat lokal sebagai tempat Raja Jayabaya melakukan penyucian sebelum ke alam baka. Saat ini, Sendang Tirto Kamandanu digunakan sebagai tempat menyucikan diri sebelum berziarah ke Pamukasan Aji Jayabaya. Selain wisatawan domestik, wisatawan mancanegara turut pernah berkunjung. Di lokasi terdapat empat tembok luar Sendang Tirto Kamandanu terdapat empat arca yaitu Brahma, Wisnu, Bayu, dan Indra. Menurut juru kunci Mbah Suratin akan lebih banyak kunjungan pada bulan syuro dalam rangka mencari berkah. Tidak ada biaya masuk tempat wisata meski dengan waktu kunjungan mulai pagi sampai malam hari. Pengunjung hanya akan dimintai sumbangan seikhlasnya yang digunakan untuk mengelola Sendang Tirto Kamandanu dan membayar parkir sebesar 2000 rupiah.

2. Buah Belimbing

Menurut kepala desa buah Belimbing merupakan salah satu potensi dari Desa Menang. Pada mulanya hal ini dilakukan oleh salah seorang warga yang diikuti oleh warga lainnya menanam pohon Belimbing di pekarangan depan rumah yang kemudian menjadi pemandangan saat memasuki Desa Menang.

Jenis Belimbing bangkok merah menjadi unggulan dari Desa Menang untuk dibudidayakan sebagai upaya meningkatkan perekonomian warga yang terbilang menengah ke bawah dengan keadaan infrastruktur desa yang kurang diperhatikan oleh pemerintah. Warga Desa Menang memiliki kompetensi buah Belimbing bibit unggul. Hasil panen raya buah Belimbing memperoleh 1 ton/ha. Aksesbilitas jalan pada lahan tanam cukup memadai meski sebagian jalanan aspal tampak rusak atau berlubang. 


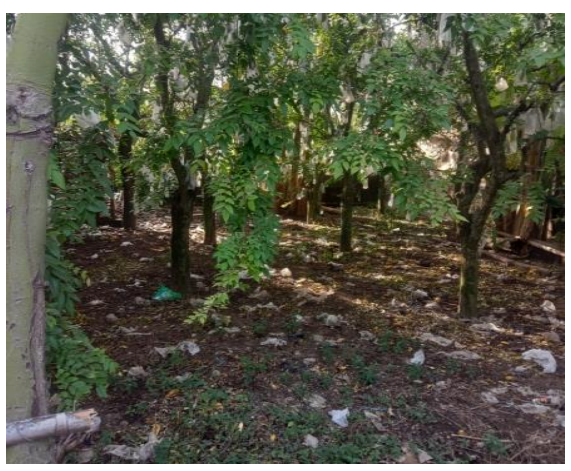

Gambar 3. Potensi Buah Belimbing Desa Menang

(Sumber: Data Primer)

Menurut paparan Ibu Lastri salah satu anggota PKK, olahan Belimbing bangkok merah yang dijadikan sebagai brand adalah dodol MENSO (Menang Suko). Dodol dikemas dalam bentuk plastik lonjong dan dipasarkan oleh masyarakat sekitar sebagai oleh-oleh wisatawan dibandrol harga dodol Rp 10.000,- per kotak.

Selain itu produk lain yakni sari buah Belimbing CARMENSO (Catur Tirta Menang Suko). Kemasan sari buah Belimbing berupa gelas plastik satuan seharga Rp 3000,- dan kemasan botol plastik satuan seharga Rp 5.000,- .

Menurut Bu Lastri bahwa anggota PKK dan konsumen dapat memesan produk sesuai dengan permintaan. Produk sari buah Belimbing mengalami peningkatan pemesanan pada saat memasuki hari lebaran Idul Fitri baik dalam daerah dan luar daerah sebagai sajian di hari raya. Olahan sari buah Belimbing ini juga dijual oleh masyarakat di lokasi desa wisata yang dapat dinikmati secara langsung namun juga dapat dibawa pulang untuk oleh-oleh.

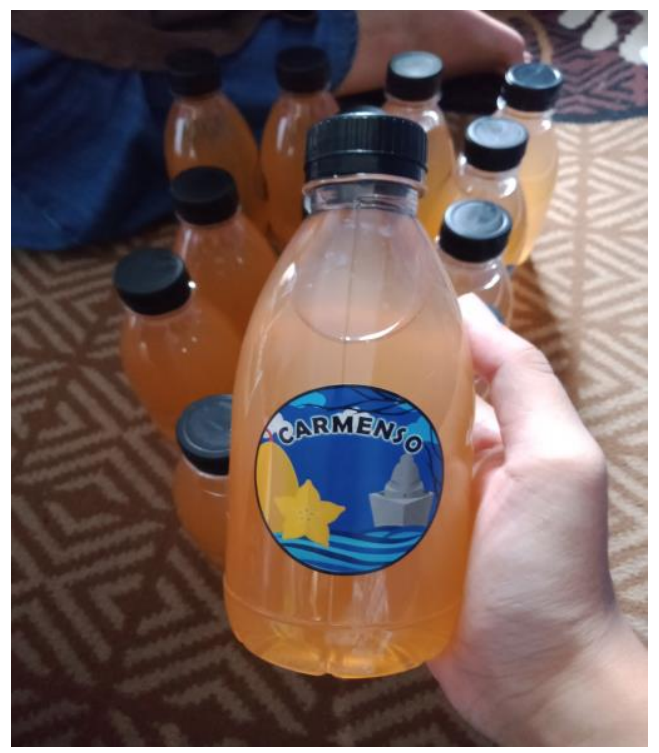

Gambar 4. Kemasan Botol Sari Buah Belimbing (Sumber: Data Primer) 


\section{Pendorong dan Penghambat Pengembangan Desa Wisata}

Pada proses pengembangan desa wisata perlu bersamaan dengan keikutsertaan masyarakat (Ratnaningsih \& Mahangga, 2015). Walaupun keikutsertaan masyarakat Desa Menang bukan penentu berhasil atau tidaknya tujuan dari desa wisata, masyarakat Desa Menang mempunyai peran khusus untuk mewujudkan tujuan yang telah dibuat di awal. Beberapa pendorong dan penghambat dari pengembangan desa wisata sebagai berikut:

1. Pendorong Pengembangan Desa Wisata Menang

a. Semangat partisipasi masyarakat dalam perencanaan pengembangan desa wisata Menang.

Masyarakat Desa Menang memiliki keinginan untuk mengembangkan desa wisata. Menurut informasi dari kepala dusun, telah dibentuk Kelompok Sadar Wisata (Pokdarwis). Hal tersebut, menurutnya dapat memberikan dorongan kepada masyarakat untuk berpartisipasi dalam mengembangkan desa wisata, sehingga memperlancar dalam proses pembangunan.

Partisipasi dari masyarakat sebagai pendukung pengembangan desa wisata ditandai dengan semangat keterlibatan warga sebagai anggota pengurus Pokdarwis. Peran tersebut menjadi penghubung musyawarah warga dan pemerintah desa sebagai upaya proses tujuan mewujudkan keberhasilan bersama mengembangkan desa wisata Belimbing dan Wisata Petilasan Sri Aji Jaya Baya.

b. Meningkatkan ekonomi masyarakat Desa Menang

Ekonomi merupakan salah satu wujud penunjang kehidupan sehari-hari. Berdasarkan informasi Kepala Dusun bahwa jumlah warga Menang sebagai petani lebih banyak dibanding pegawai tetap institusi pemerintahan maupun swasta. Pengembangan desa wisata berdampak pada perekonomian masyarakat yang mengalami peningkatan. Agus (45 tahun) seorang buruh tani dan memiliki pekerjaan sampingan sebagai tukang parkir di tempat wisata. Pekerjaan keduanya tersebut menjadi tambahan pemasukan setiap hari. Mujiyem (34 tahun) yang tinggal di RT 02/RW 01 Desa Menang bekerja sebagai buruh tani yang memperoleh tambahan pendapatan harian dari hasil penjualan bibit dan buah Belimbing. Hasil tersebut telah membantu perekonomian keluarga Mujiyem meski hasil pendapatan penjualan terbilang tidak signifikan. Kemudian, Lastri (40 tahun) bertempat tinggal di RT.03/RW.02 Desa Menang yang berjualan makanan instan, makanan ringan (gorengan), dan sari buah Belimbing. Pendapatan Lastri meningkat sejak adanya desa wisata. Sebelumnya pendapatan dari warungnya di rumah sebesar Rp 300.000,- per hari, sedangkan sesudahnya pendapatan sebesar Rp 500.000,- per hari.

2. Penghambat Pengembangan Desa Wisata Menang

a. Sosialisasi dan pelatihan yang kurang

Menurut Kepala Dusun bahwa tahap sosialisasi yang diberikan kepada masyarakat terkait cara pengembangan desa wisata terbilang kurang. Hal tersebut mempengaruhi partisipasi dari masyarakat. Tanpa adanya sosialisasi, masyarakat tidak mengetahui cara untuk mengembangkan desa wisata. Apabila pada level dasar belum dilakukan secara maksimal maka untuk melaksanakan tahap kelanjutan menjadi terhambat. Sosialisasi yang pernah diberikan hanya sekali kepada masyarakat melalui kepala dusun tanpa mengundang pemateri yakni pihak dinas UMKM. Hal ini menyebabkan masyarakat tidak mendalami terkait pengembangan desa wisata. 
Masalah yang dihadapi lainnya yaitu pertama, sarana dan prasarana penunjang desa wisata yang masih kurang seperti tidak adanya tempat sampah dan bank sampah. Kedua, belum optimal dalam pengelolaan limbah daun Belimbing. Ketiga, kurang tertatanya pohon Belimbing di setiap rumah warga, sehingga pohon Belimbing terlihat kurang menarik. Keempat, kurangnya pelatihan dalam mengelola pengurusan perizinan industri rumah tangga pembuatan dodol buah Belimbing. Kelima, pola kebijakan yang terencana kurang siap dijalankan. Keenam, promosi di media sosial terhenti karena masalah biaya.

b. Rendahnya kesadaran masyarakat

Kesadaran warga Desa Menang merupakan faktor utama mewujudkan desa wisata. Mengingat jumlah pekerjaan warga sebagai petani lebih tinggi berakibat pada waktu bekerja di pagi hari hingga sore untuk mengelola sawah. Maka dapat disimpulkan jika warga Desa Menang mempunyai kesadaran yang rendah dalam berpartisipasi mengembangkan desa wisata.

\section{Bentuk Partisipasi Masyarakat Desa Menang}

Desa Menang merupakan salah satu desa wisata di Kabupaten Kediri. Partisipasi aktif dari masyarakat menjadi pokok utama dalam mengembangkan desa wisata (Palimbunga, 2017).

Partisipasi aktif dari masyarakat yang diharapkan yakni pertama, partisipasi ide. Berdasarkan temuan diperlukan ide dari masyarakat melalui musyawarah dan rapat desa, mengingat masyarakat yang mengetahui permasalahan dan keperluan untuk mengembangkan desa wisata ke arah yang lebih maju. Ide dan musyawarah masyarakat ditampung oleh Pokdarwis (Kelompok Sadar Wisata) Desa Menang. Kedua, bentuk partisipasi tenaga dalam mengembangkan desa wisata Menang. Bentuk partisipasi tenaga warga di lokasi wisata Petilasan Sri Aji Jaya Baya yakni dengan berprofesi sebagai penjual olahan buah Belimbing, petugas kebersihan, penjaga, dan tukang parkir. Ketiga, bentuk partisipasi kreativitas dan inovasi dari masyarakat terwakilkan oleh kelompok karang taruna. Perkumpulan karang taruna Desa Menang memberikan dorongan patisipasi dalam pengembangan desa wisata baik tenaga, gagasan dan ide kreatif, seperti melakukan promosi melalui media sosial yaitu instagram. Contohnya, kegiatan suro di Petilasan Sri Aji Jaya Baya.

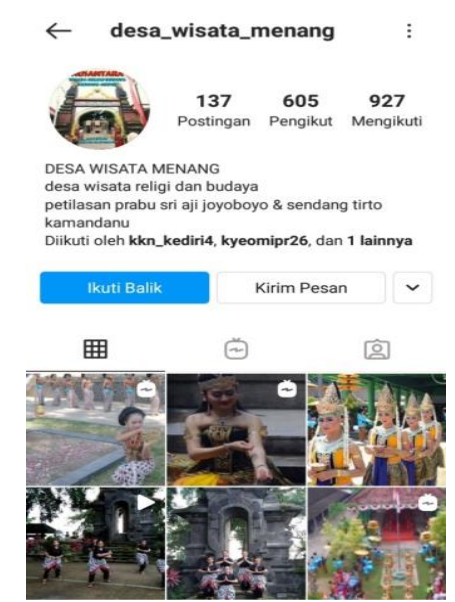

Gambar 5. Promosi Desa Wisata Menang

(Sumber: Instagram @desa_wisata_menang) 


\section{Tindakan Sosial Masyarakat Menang Berpartisipasi dalam Mengembangkan Desa Wisata Menurut Pandangan Max Weber}

Desa wisata merupakan salah satu wujud pariwisata berbasis masyarakat. Desa Menang dalam tahap pengembangan desa wisata didasarkan pada partisipasi dari masyarakatnya. Akan tetapi, hal ini menjadi permasalahan tersendiri apabila kesadaran rendah dari masyarakat dalam mengembangkan desa wisata.

Membangun desa wisata membutuhkan proses pengembangan secara maksimal yaitu dengan perencanaan yang baik sehingga harapan dari seluruh masyarakat dapat terwujud. Berdasarkan temuan bahwa pengembangan desa wisata di Desa Menang didalamnya terdapat tujuan masyarakat. Hal tersebut selaras dengan teori tindakan sosial dari Max Weber. Menurut Weber setiap manusia dalam bertindak mempunyai tujuan tertentu di dalamnya (George, 2007:50). Hal itu berupa empat tindakan sosial yakni rasionalitas intrumental, rasionalitas nilai, tindakan afektif, dan tindakan tradisional (George \& Douglas, 2009:136).

Berdasarkan temuan, tindakan rasionalitas instrumental yakni tindakan sosial yang didasarkan pada tujuan yang ingin dicapai. Warga Desa Menang dalam berpartisipasi mengembangkan desa wisata tidak hanya ingin mencapai tujuannya. Akan tetapi, dalam mengembangkan desa wisata sebelumnya telah memperhitungkan keuntungan dan kerugiannya. Keuntungan yang telah dipertimbangkan yakni dengan adanya desa wisata dapat membantu meningkatkan ekonomi masyarakat. Warung yang berada di sekitar Desa Menang mengalami penambahan pendapatan sebab banyak wisatawan yang datang untuk melihat desa wisata. Membuka lapangan pekerjaan untuk masyarakat Desa Menang.

Tindakan rasionalitas nilai yakni tindakan sosial yang ingin dicapai didasarkan pada nilai. Pengembangan desa wisata menurut kepala desa dapat memberikan atau menambah kesejahteraan masyarakat melalui peningkatan ekonomi masyarakat. Tindakan afektif yakni tindakan yang didasarkan pada emosi. Masyarakat Desa Menang dalam mengembangkan desa wisata didasarkan pada kesadaran dan kemauan dari diri sendiri. Adanya kerja sama dari masyarakat dapat menumbuhkan solidaritas antar sesama. Solidaritas yang tercipta dapat membangun kesatuan di antara sesama masyarakat dalam mengembangkan desa wisata. Tindakan tradisional yakni tindakan yang didasarkan pada kebiasaan atau warisan dari nenek moyang. Desa wisata ini telah dikembangkan nenek moyang. Kelanjutannya warga Desa Menang mengembangkan dan memberikan inovasi yang baru.

\section{Kesimpulan}

Berdasarkan temuan di atas bahwa potensi Desa Menang yaitu pertama, Petilasan Sri Aji Jaya Baya. Petilasan Sri Aji Jaya Baya merupakan salah satu peninggalan sejarah Kerajaan Kadiri. Wisata ini sering dikunjungi oleh masyarakat baik dari dalam daerah maupun dari luar daerah. Kedua, menurut kepala desa bahwa buah Belimbing bangkok merah merupakan salah satu potensi dari Desa Menang. Pada mulanya terdapat salah satu warga Desa Menang yang menanam pohon Belimbing, selanjutnya warga lainnya mengikuti menanam pohon Belimbing di depan rumah dan kemudian menjadi sebagai tambahan sumber pendapatan.

Berdasarkan partisipasi masyarakat dalam mengembangkan desa wisata sesuai dengan 4 tindakan sosial dari Max Weber yaitu tindakan rasionalitas instrumental, tindakan rasionalitas nilai, tindakan afeksi, dan tindakan tradisional. Tindakan rasionalitas instrumental yakni tindakan 
sosial yang didasarkan pada tujuan yang ingin dicapai. Warga Menang dalam mengembangkan desa wisata sebelumnya telah memperhitungkan keuntungan dan kerugiannya. Keuntungan yang telah dipertimbangkan dengan adanya desa wisata yaitu dapat membantu meningkatkan ekonomi masyarakat. Tindakan rasionalitas nilai yakni tindakan sosial yang ingin dicapai didasarkan pada nilai. Pengembangan desa wisata menurut kepala desa dapat memberikan atau menambah kesejahteraan masyarakat melalui peningkatan ekonomi masyarakat. Tindakan afektif yakni tindakan yang didasarkan pada emosi. Masyarakat Desa Menang dalam mengembangkan desa wisata didasarkan pada kesadaran dan kemauan dari diri sendiri. Tindakan tradisional yakni tindakan yang didasarkan pada kebiasaan atau warisan dari nenek moyang. Desa wisata ini telah dikembangkan nenek moyang, selanjutnya warga Desa Menang mengembangkan dan memberikan inovasi baru.

\section{Daftar Pustaka}

Abawin, H. (2019). Peningkatan Kesejahteraan Ekonomi Masyarakat Melalui Pengembangan Desa Wisata Bebasis Agrowisata (Studi Kasus di Desa Sawahan Kecamatan Watulimo Kabupaten Trenggalek.

Afriesta, C. L. B., Kurniawan, H. E., N., S. N., \& Ekasiwi. (2020). Korelasi Antara Push dan Pull Factor Wisata Kawasan dan Bangunan Bersejarah. Jurnal Pariwisata Terapan, 4(1). https://doi.org/https://doi.org/10.22146/jpt.46036

Irtifah, \& Bondowoso, M. N. J. (2019). Peningkatan Ekonomi Desa Melalui Wisata Alam. Media Mahardika, 17(2).

Paskasari, Clara Shinta., Guntoro, Budi., \& Witjaksono. (2020). Kapasitas Kelembagaan Pengelola Desa Wisata Brajan Kabupaten Sleman. Jurnal Pariwisata Terapan, 4(1).https://doi.org/10.22146/jpt.48259

Palimbunga, I. P. (2017). Bentuk Partisipasi Masyarakat Dalam Pengembangan Pariwisata di Kampung Wisata Tablanusu Kabupaten Jaya Pura Provinsi Papua. Kajian Sastra Dan Bahasa, 1(2).

Paramitha, O. D., Kagungan, D., \& Mulyana, N. (2020). Strategi Kelompok Sadar Wisata (Pokdarwis) Dalam Pengembangan Pariwisata Berbasis Pemberdayaan Masyarakat di Kabupaten Tanggamus. Administrasi, 2(1).

Ratnaningsih, N. L. G., \& Mahangga, I. G. A. O. (2015). Partisipasi Masyarakat Lokal Dalam Pariwisata. Destinasi Pariwisata, 3(1).

Ritzer, G. (2007). Sosiologi Ilmu Pengetahuan Berparadigma Ganda. Jakarta: PT. Raja Grafindo Persada.

Ritzer, G., \& Douglas, J. G. (2008). Teori Sosiologi Modern. Jakarta: Kencana.

Ritzer, G., \& Goodma, D. (2009). Teori Sosiologi Modern; Dari Teori Sosiologi Klasik Sampai Perkembangan Mutakhir Teori Sosiologi Postmodern. Yogyakarta: Kreasi Wacana.

Simanungkalit, V. br., Sari, D. A., Teguh, F., Ristanto, H., Permanasari, I., Sambodo, L., ... Vitriani, D. (2019). Buku Panduan Pengembangan Desa Wisata Hijau. (CresentiaNovinti, Ed.). Jakarta Selatan: Asisten Deputi Urusan Ketenagalistrikan dan Aneka Usaha.

Sugiono. (2013). Metode Penelitian Pendidikan Pendekatan Kuantitatif, Kualitatif, dan R\&D. Bandung: Alfabeta.

Suharto, E. (2005). Membangun Masyarakat Memberdayakan Masyarakat. Bandung: PT Refika 
Maya Sajidah Salsabila

Aditama.

Sunarta, N., \& Arida, N. S. (2017). Pariwisata Berkelanjutan (Cetakan pe). Bali: Cakra Press. 